\title{
THE SHAPE OF THE LEMURU FISH MARKET IN TERMS OF MARKET STRUCTURE ANALYSIS (CASE STUDY IN MUNCAR SUBDISTRICT, BANYUWANGI REGENCY, EAST JAVA)
}

\author{
Aditya Bagus Wicaksana*, Budi Setiawan, Abdul Wahib Muhaimin \\ Faculty of Agriculture, Brawijaya University, Indonesia \\ *corresponding author: abaguswicaksana@ gmail.com
}

\begin{abstract}
This study aims to analyze the structure of the Lemuru fish market that was formed in Muncar District, Banyuwangi Regency. There are two respondents, fishermen (61 people) and marketing agencies (25 people). The sampling method used random sampling and slovin calculations to determine the number of fishermen respondents, the sample of marketing institutions used the snowball sampling method. To determine the market structure, the analysis used is identifying the number of marketing institutions, market concentration using market share and CR4, product differentiation, and barriers to market entry. The results show that there are two marketing channels. Marketing channel one consists of 50 fishers, five collectors, and seven retailers. Channel two consists of 11 fishers and 13 retailers. From the analysis of market concentration using market share and CR4 at the fisherman and retailer level, a perfect competition market and a monopoly competition market at the collector level are formed. There is no product differentiation made by fishers, collectors, and retailers. The barriers to entry and exit from the market faced by fishers are natural and non-natural barriers, while collectors and retailers face non-natural barriers.
\end{abstract}

Keywords: number of marketing agencies, market concentration, product differentiation, the barriers to entry.

http://dx.doi.org/10.21776/ub.agrise.2022.022.1.7

Received 8 July 2021

Accepted 25 January 2022

Available online 31 January 2022

\section{INTRODUCTION}

In production, development of lemuru production in Indonesia at 2011 was 32,475 tons. In 2012 it increased by $41 \%$ to 45,807 tons, decreased by $0.14 \%$ in 2013 to 45,740 tons, and increased by $15 \%$ in 2013. in 2014 to 53,895 tons. The Muncar area in Banyuwangi Regency is one of the largest Lemuru producing areas in East Java. This area, which is located in the south of Banyuwangi Regency, is directly adjacent to the Bali Strait and is crossed by the Wallace line as a migration site for several types of lemuru (Pradini et al., 2001), thus enabling the waters to have an abundant diversity of lemuru species. It is in line with the opinion of
Purwaningsih (2015), wherein 2009, the number of fish landed at PPP Muncar was 34 thousand tons of fish, of which 28 thousand tons were lemuru.

In general, the marketing of fishery products is potentially inefficient. It is because fishery commodities have distinctive characteristics, namely Perishability (perishable), Seasonal (seasonal), Bulkiness (requires ample and refrigerated space for fresh fish storage), and Nonhomogeneity (non-uniform) (Abidin et al., 2017). Due to the unique characteristics of these fish, many intermediary traders are involved increasing total marketing costs where this allows

CITATION: Wicaksana, A. B., Setiawan, B., Muhaimin, A. W., (2022). THE SHAPE OF THE LEMURU FISH MARKET IN TERMS OF MARKET STRUCTURE ANALYSIS (CASE STUDY IN MUNCAR SUBDISTRICT, BANYUWANGI REGENCY, EAST JAVA), Agricultural Socio-Economics Journal, 22(1), 47-52 DOI: http://dx.doi.org/10.21776/ub.agrise.2022.022.1.7 
for a share that is not commensurate with the costs incurred by market participants.

From KKP data for 2016-2020, it is known that the average price margin of producers and consumers is more than $50 \%$. Theoretically, this condition shows the small share value received by fishers. The smaller the farmer's share value, it can be said that the marketing channel is not efficient (Sustiyana \& Iswahyudi, 2019). Therefore, there is a need for research related to analyzing the market structure of lemuru fish in Muncar District, Banyuwangi Regency.

This study raises the issue of the causes of marketing inefficiency in Muncar District, Banyuwangi Regency. Analysis of market structure needs to be done to know the causes of the inefficiency of the Lemuru fish market. One of the analyses that can be done to determine market inefficiency is analyzing the structure contained in a market (Anindita and Baldina, 2017). It agrees with Soekartawi (2005), that one of the techniques that can be used to improve marketing efficiency is to know the shape of the market structure.

\section{RESEARCH METHODS}

\section{Research Sites and Responden Samples}

This research was conducted in Taebenu Subdistrict, Kupang Regency, East Nusa Tenggara Province, Indonesia. The research time took place in January-March 2021. Samples of livestock farmers are taken using a simple random sampling method based on wild cattle farmers and non wild cattle farmers (privately owned). The number of cattle farmers sampled amounted to 100 divided into two groups, namely group I: 50 row cattle farmers and group II: 50 non-row cattle farmers. The calculation of the respondent's sample using slovin formula (Nugraheni et al., 2018) namely $\mathrm{n}=\mathrm{N} /(\mathrm{N} . \mathrm{d} . \mathrm{d}+1)$ where $\mathrm{n}=$ sample size, $\mathrm{N}=$ population size, $\mathrm{d}=$ guessing error $(10 \%)$.

\section{Data Analysis Techniques}

In this research, the data used are primary data and secondary data. Primary data were obtained from direct interviews with Lemuru fish marketers and related marketing institutions in Banyuwangi Regency using the questionnaire method. The researcher conducted and guided the interview process without intervening with the informants. In addition to conducting interviews with resource persons to obtain primary data, the researchers also observed the natural process of the Lemuru fish marketing chain. This observation was carried out to get a clear picture of the marketing process of lemuru fish that occurred in the Banyuwangi Regency. Secondary data collection is collected from media such as East Java BPS, Banyuwangi district BPS, Banyuwangi District Revenue Agency, and Banyuwangi Fisheries Service.

Data obtained from interviews with respondents and direct surveys in the field were processed and tabulated. Furthermore, the data results were analyzed using market share, market concentration, product differentiation, and barriers to market entry.

Market share can be calculated using the formula $\mathrm{MSn}=\mathrm{Si} / \mathrm{Stot} \times 100 \%$ where:

MSn: Lemuru fish traders market share (percent)

$\mathrm{Si}$ : Sales of Lemuru fish to the nth trader (kg/month)

Stot : Total sales of Lemuru fish at the Fish Landing Port (kg/month)

From the results of these calculations, it can be seen that the monopoly market structure by marketing actors is formed if the calculation results get a value of $100 \%$. An oligopoly market will be formed if the four highest marketing actors produce $40 \%$ to more or less or equal to $100 \%$. A monopolistic market will be formed if the calculation results get a number less than or equal $10 \%$ of the number of competitors in the marketing channel. A perfect competition market will be formed if more than 50 competitors and the calculation value is below $10 \%$.

While market concentration can be calculated using the formula:

$$
\text { CR4 }=\frac{\Sigma \text { Ms4 }}{\Sigma \text { Ms tot }} \times 100 \%
$$

Where:

CR4 : the concentration ratio of the four largest companies

$\sum$ Ms4 : the amount of market share of the four largest buyers

$\sum$ Mstot : the amount of market share throughout the market

From these calculations, there are three criteria: first, if the value of the gain calculation CR4 value of more than $40 \%$, it can be concluded that the market formed on the market structure is perfect or monopolistic competition. If the result of the calculation is to get the value of $40 \%-80 \%$, the market competition is formed oligopoly market competition and oligopsony. In contrast, the third when the value of CR4 generated more than $80 \%$ of 
the formed market structure is a competitive market monopoly and monopsony.

\section{RESULTS AND DISCUSSION}

\section{Analysis of several indicators to determine the structure of the Lemuru fish market in Muncar District, Banyuwangi Regency, East Java Province, Indonesia.}

\section{Comparison of The Number of Sellers and Buyers}

From the data collected, it can be seen that the producers of Lemuru fish in Muncar District are fishermen. In contrast, the Lemuru fish marketing institution consists of collectors and retailers where it is necessary to observe the comparison between the number of sellers and buyers at each level of existing marketing institutions. There are two marketing channels for Lemuru fish in Muncar District. Channel one consists of fishers, collectors, and retailers. Channel two consists of fishers and retailers. The following is a comparison table between fishers, collectors, and retailers.

\begin{tabular}{|c|l|c|c|}
\hline $\begin{array}{c}\text { Marketing } \\
\text { Channel }\end{array}$ & \multicolumn{1}{|c|}{ Market Level } & $\begin{array}{c}\text { Number of Sellers } \\
\text { (Person) }\end{array}$ & $\begin{array}{c}\text { Number of Buyers } \\
\text { (Person) }\end{array}$ \\
\hline \multirow{4}{*}{1} & Fishermen-Collectors & 50 & 5 \\
\cline { 2 - 4 } & Collector-Retailer cooperation & 5 & 7 \\
\cline { 2 - 4 } & Retailer cooperation-Consumer & 7 & Much \\
\cline { 2 - 4 } & Fishermen-Collectors & 50 & 5 \\
\cline { 2 - 4 } & Collector-Retailer & 5 & 13 \\
\cline { 2 - 4 } & Retailer-Consumer & 13 & Much \\
\hline \multirow{2}{*}{2} & Fisherman-Retailer & 11 & 13 \\
\cline { 2 - 4 } & Retailer-Consumer & 13 & Much \\
\hline
\end{tabular}

Source: Processed from primary data, 2021.

From the above table, it can be seen that in every marketing channel, lemuru number of sellers outnumber buyers except at the level of the collectors market to retailers.

\section{Market Concentration}

From the data analysis conducted in market share from the fishers, there are 61 competitors at the level of the fishers with the highest value market share of $5 \%$, while the lowest market share is $1 \%$. From the data analysis, we can conclude that the market competition is formed at the fisherman is a perfectly competitive market as the result of the analysis showed that there were more than 50 competitors at the level of a fisherman with a value market share below $10 \%$.

There are two classifications at marketing institutions at the level of fish traders in Lemuru in Muncar District, namely collectors and retailers where there are five collectors and 20 retailers. The following is an analysis of market share at the level of collectors.

\begin{tabular}{|c|c|c|c|c|c|c|}
\hline No & $\begin{array}{c}\text { collector's } \\
\text { Name }\end{array}$ & Production & $\begin{array}{c}\text { Concentration } \\
\text { Ratio }\end{array}$ & $\begin{array}{c}\text { Market } \\
\text { Share }\end{array}$ & $\begin{array}{c}\text { Market Share } \\
\text { Cumulative }\end{array}$ & \multirow{2}{*}{ CR4 } \\
\hline 1 & BS & 2000 & 0,4 & 40 & 40 & \multirow{2}{*}{90} \\
\hline 2 & AS & 1000 & 0,2 & 20 & 60 & \\
\hline 3 & AH & 1000 & 0,2 & 20 & 80 & \\
\hline 4 & BJ & 500 & 0,1 & 10 & 90 & \\
\hline 5 & FA & 500 & 0,1 & 10 & 100 & \\
\hline & & 5000 & 1 & 100 & & \\
\hline
\end{tabular}

Source: Processed from primary data, 2021.

From the above table, it can be seen that the highest market share in the fish market Lemuru is $40 \%$. The lowest market share is $10 \%$. From the data in the table, it is also known that the market share value shows results above $10 \%$. Therefore, it is necessary to do a CR4 analysis to determine the shape of the market structure of lemuru fish at the level of collectors.

In the analysis of market share at the level of retailers, note that the value of the highest market share in the fish market Lemuru is $8.75 \%$. As the value of its lowest market share was $2.5 \%$. When seen from the market share, which formed no single value market share of more than $10 \%$, it shows that market competition tends to form a perfectly competitive market, however, it should be recalled that at the level of retailers, respondents recorded fewer than 50 people where the need for an analysis of market competition CR4 to know what is formed.

Concentration Ratio for Biggest Four

(CR4) is a tool that can be used to analyze the market structure and market concentration of the four most significant market shares (Baye, 2010). Therefore, in this research, CR4 analysis was carried out on the four most significant market share values formed by fishers, collectors, and retailers, from the analysis made known that CR4 value of the fishers is $18 \%$. From the CR4 value at the fisherman's level, it can be concluded that the competitive market formed at the fisherman's level is a perfectly competitive market. At the level of collectors, based on the analysis that has been done, it can be seen that the CR4 value formed is $90 \%$. From these data, it can be concluded that the four collectors in the Lemuru fish market control $90 \%$ of the market. From these data, we can conclude that the market competition is formed at the fish market is a competitive market monopoly Lemuru because the value of CR4 formed more than $80 \%$. Based on the analysis, the level of retailers made known that $\mathrm{CR} 4$ generated value is $30 \%$. These results show that the four biggest retailers control 30\% Lemuru fish market. Because the value of CR4 formed in the retailer is under $40 \%$, and there is no differentiation in fish Lemuru products sold (homogeneous), it can be concluded that the market competition that is formed is a perfectly competitive market.

The following will present the CR4 value of 
fishers and marketing institutions in the Lemuru fish marketing channel.

\begin{tabular}{|c|c|c|c|}
\hline No & Marketing Agency & $\begin{array}{c}\text { CR4 } \\
\text { Value }\end{array}$ & Market Structure \\
\hline 1 & Fisherman & 18 & Perfect \\
\hline 2 & Collector & 90 & Monopoli \\
\hline 3 & Retailer & 30 & Perfect \\
\hline
\end{tabular}

Source: Processed from primary data, 2021.

The highest CR4 value from fishers and fish marketing institutions in Lemuru is for collectors with a value of $90 \%$. The high value of CR4 causes a market concentration. This condition impacts the higher bargaining power that collectors can provide to other marketing institutions. In addition, these conditions can also impact the low level of market competition that occurs and tends to lead to monopolistic competition markets. The condition is in line with research Soung-hun (2008), which is that more concentrated marketing agencies have a stronger bargaining power against business partners in upstream or downstream, thus making transactions more profitable.

\section{Product Differentiation}

Product differentiation analysis carried out in this study is the treatment of Lemuru fish on fishers, collectors, and retailers. The treatment in question is the process of fishers, collectors, and retailers in increasing the value of Lemuru fish by processing it. From the data from interviews that have been carried out, it is known that there has been no product differentiation effort carried out by fishers, collectors, and retailers in the Lemuru fish market. The product sold in the marketing of Lemuru fish is fresh Lemuru fish with the same treatment for every existing business actor, namely maintaining the freshness level of Lemuru fish. As for how that is done to maintain the freshness of the fish, Lemuru level is to add ice to the storage area lemuru.

In terms of effort or strategy undertaken to increase the value of fish Lemuru, the marketing institution has not done changing shape (form utility) in fish Lemuru. These results are similar to studies conducted by Apriono et al, (2012) concerning the marketing of fish catfish, Azhara, (2016) concerning the marketing of fish milkfish in West Java, Nendissa et al., (2018), related to the marketing of beef cattle in East Nusa Tenggara. The addition value (value-added) needs to be done, especially at the level of the fishers, to increase the bargaining power of the products they produce.

On the other hand, the fishers have several treatments to go to product differentiation. Some of these treatments are sorting activities Lemuru quality fish of the size and extent of the damage. Some of these treatments aim to influence consumer perceptions of the quality of products and the buying decision.

\section{Barriers to Market Entry}

There are two aspects of barriers to entry and exit from the market: natural and non-natural barriers. A survey conducted by researchers notes that officially there are government regulations that apply concerning fishing in the district Muncar. Regulation in question is a regulation on government regulation of the Kementrian Kelautan dan Perikanan (2020) related to fishing license (SIPI), licenses to fishing business (SIUP), sign the list of fishing vessels (TDKP), and permit fish transport vessel (SIKPI) issued by the Governor where licensing becomes non-natural obstacle for fishers and fish marketing agencies Lemuru. The period of validity of the license fishing effort can be seen in the following table.

\begin{tabular}{|c|l|c|}
\hline No & \multicolumn{1}{|c|}{ License } & Validity period \\
\hline 1 & Fishery business license (SIUP) & 30year \\
\hline 2 & Fishing license (SIPI) & 1year \\
\hline 3 & Fish transport vessel license (SIKPI) & 1year \\
\hline 4 & Fishing vessel registration sign (TDKP) & During fishing \\
\hline
\end{tabular}

Source: Ministry of Marine Affairs and Fisheries, processed, 2020.

From the period of validity of licenses required to conduct fishery business, the need for extension of the validity period of SIPI and SIKPI annually can be seen. Although the business license management has been done electronically, this has become an obstacle for fishers because they have to take care of the two permits every year. On the other hand, the lack of knowledge of fishers on technological developments related to the electronically processing of fishery business permits is a separate obstacle.

The fish auction facilities in the port of Muncar aim to increase fishermen's bargaining power to catch results, but when surveying the field, it is known that the auction contained in Muncar port is not running. It can be seen from the control over catch of fish by collectors because of the relationship of capital cooperation between fishers and collectors. The condition relating to the existence of non-nature market entry barriers for new merchants that will go to the fish market Lemuru.

From the conditions in the field described previously, at the fisherman's level, the existing barriers to entry and exit from non-natural markets are regulations for fishing businesses. Meanwhile, barriers to entry and exit from the market at the fisherman's level are naturally erratic weather changes. At the marketing agency at the collector 
level, there are barriers to entry and exit from the market. The formation of a monopoly market at the marketing agency at the level of collectors makes it difficult for new collectors to enter the Lemuru fish market. In addition, the limited capital of fishers causes fishers to establish cooperative relationships with capital loans to collectors in the form of fishing catches that must be sold to collectors who provide capital loans, making it difficult for new collectors to enter the Lemuru fish market. At the retailer level, barriers to entry and exit in the Lemuru fish market are non-natural barriers. The obstacle is the existence of cooperation between collectors and retailers.

\section{CONCLUSION}

In the analysis of the market structure of lemuru fish with an indicator of the comparison of the number of sellers and buyers, it is known that there are two marketing channels where each marketing channel has more sellers of lemuru fish than the number of buyers except at the collectors to retail market level. While in the analysis of market concentration, it can be seen that a perfectly competitive market occurs in fishers and retailers, while a monopoly market is formed in collectors. In the product differentiation indicator, the analysis results show that there is no differentiation process carried out by fishers, collectors, and retailers. While the results of the analysis of barriers to entry and exit from the market for fishers, there are non-natural obstacles, namely the regulation of capture fisheries business permits and natural obstacles, namely changes in weatherrelated to fishermen's catches. Barriers to entry and exit from the market for collectors are non-natural barriers, namely the cooperation between collectors, fishers, and retailers to dominate the market. As for retailers, the non-natural obstacle that is formed is the cooperation of several retailers and collectors to dominate the Lemuru fish market.

\section{RECOMENDATION}

Need for counseling Lemuru fish processing, especially the fishers from the local government to add value to the fish Lemuru and bargaining power possessed by fishers.

\section{REFFERENCE}

Abidin, Z. Harahab, N. Asmarawati, L. 2017. Pemasaran Hasil Perikanan. Malang: UB Press.
Anindita, R dan Baladina, N. 2017. Pemasara Produk Pertanian. Penerbit Andi Ofcet. Yogyakarta.

Apriono D, Dolorosa E, Imelda. 2012. Analisis efisiensi saluran pemasaran ikan lele di desa rasau jaya 1 kecamatan rasau jaya Kabupaten Kubu raya. Journal Socio Economic of Agriculture [Internet]. [diunduh tanggal 2020 jan 16]; 1(3):29-36.

Azhara, D. 2016. Struktur, Perilaku dan Kinerja Pemasaran Ikan Bandeng di Jawa Barat. Tesis. Institut Pertanian Bogor.

Kementerian Kelautan dan Perikanan. 2020. Peraturan Menteri Kelautan Dan Perikanan Republik Indonesia Nomor 58/PermenKP/2020 Tentang Usaha Perikanan Tangkap.

Nendissa, D. R., Anindita, R., Hanani, N., \& Muhaimin, A. W. (2018). Dynamics of Degree of Beef Cattle Market Concentration in Kupang of East Nusa Tenggara, Indonesia. Russian Journal of Agricultural and SocioEconomic Sciences, 78(6), 379-384

Nugraheni, D., Saputra, M. C., \& Herlambang, A. D. (2018). Analisis Penerimaan dan Kesuksesan Implementasi E-Learning Universitas Brawijaya Pada Aspek Intention To Use, Use, User Satisfaction dan Net Benefits. 2(5), 1921-1931.

Pradini, S., Rahardjo, M. E., \& Kaswadji, R. (2001). Kebiasaan Makanan Ikan Lemuru (Sardinella Lemuru) Di Perairan Muncar, Banyuwangi. Jurnal Iktiologi Indonesia, 1(1), 41-45.

Purwaningsih, R. (2015). Analisis Nilai Tambah Produk Perikanan Lemuru Pelabuhan Muncar Banyuwangi. Jurnal Ilmiah Teknik Industri, 14(1), 13-23.

Soekartawi, 2005. Prinsif Dasar Manajemen Pemasaran Hasil-hasil Pertanian, Raja Grafindo Persada, Jakarta.

Soung-hun, K. I. M. 2008. "Market Concentration of the Processed Food in Korea." Journal of Rural Development, vol. 31, no. 5, 2008, pp. 25-47

Sustiyana, \& Iswahyudi. (2019). Pola Saluran Pemasaran Dan Farmer' S Share. 3(2), 33-38. 
This page is intentionally left blank 